\title{
Kulturowy performance - Waltera Benjamina doświadczenie snu
}

Jacek Kowalski

TEKSTY DRUGIE 2016, NR 5, S. 40-55

DOI: $10.18318 /$ td.2016.5.3

\section{Słowo wstępne}

Słowo performance ${ }^{1}$ w kontekście prezentowanego szkicu rozumiem głównie jako rodzaj intelektualnej wirtuozerii, z jaką mamy do czynienia, podążając za doświadczeniem snu w rozważaniach jednego z obecnie najważniejszych niemieckich filozofów kultury XX wieku, Waltera Benjamina (1892-1940). Można mówić o performansie² także w sensie dosłownym (np. eksperymenty ze środkami odurzającymi na własnym ciele), jeśli weźmiemy pod uwagę takie książki Benjamina jak np. O haszyszu. Teksty literackie, zapiski, materiaty, do której w tej pracy będę się

1 W kontekście współczesnej myśli performatywnej, zaprezentowanej w książce Jacka Wachowskiego, "kulturowy performance" rozumiem, w sposób bardziej szczegółowy, jako akt cechujący się częściowo określonym (ale nie całkowitym) stopniem performatywności, który odnosi się do sfery materialnej (eksperymenty narkotyczne na własnym ciele) oraz kognitywnej (weryfikacja świadomości i mocy twórczej po zażyciu środka odurzającego). J. Wachowski Performans, słowo/obraz terytoria, Gdańsk 2011, s. 117-127.

2 D. Bastek Akt przemiany ciała w obraz, w: Konteksty intermedialności, red. M. Popczyk, Wydawnictwo Wyższej Szkoły Zarządzania Organizacją Pracy, Katowice 2013, s. 131. 
odwoływał. Kulturowy performance jest efektem napięcia poznawczego, jakie od zawsze towarzyszyło wysiłkom intelektualnym Benjamina, ,fundatora dyskursywności", myśliciela zawieszonego między sztuką a filozofią i nauką ${ }^{3}$. We wstępie do „Przeglądu Kulturoznawczego”" Eugeniusz Wilk pisał, że utworem, na który najczęściej powołują się badacze twórczości Waltera Benjamina, są oczywiście Pasaże $e^{5}$ Inni badacze z kolei podejmują próbę omówienia współczesnych koncepcji kulturoznawczych w świetle Benjaminowskiej tradycji. W tym tekście przedstawię w zwięzły sposób najistotniejsze elementy związane z dość, jak się zdaje, peryferyjnym, ale relewantnym doświadczeniem snu ${ }^{6}$ - ze szczególnym uwzględnieniem technicznego wymiaru analizowanego zjawiska i próbą jego odniesienia do współczesnych praktyk snu. Należy również podkreślić, że intelektualna siła Waltera Benjamina tkwi nie tylko w jego pismach, ale przede wszystkim w licznych cytatach, sentencjach i aforyzmach - jako przywoływanego w ramach dyskursu (po)nowoczesnego upadku doświadczenia: „Czytelnik flâneur, człowiek myślący bądź czekający są w równej mierze ludźmi oświeconymi, co człowiek zażywający opium, śniący [wyróż. - J.K.] lub odurzony. I są bardziej świeccy. Nie wspominając już o tym najstraszniejszym narkotyku, jaki zażywamy w samotności - o nas samych"7.

\section{Psychologizacja, historyczność snu i inne pobudki Benjamina}

Sny są częstym punktem odniesienia w zapisach i szkicach Waltera Benjamina ${ }^{8}$. Można je odnaleźć przede wszystkim w jego najważniejszym

3 A. Zeidler-Janiszewska Benjamin - tajemnica rosnącego oddziaływania, w: „Drobne rysy w ciągłej katastrofie..." Obecność Waltera Benjamina w kulturze współczesnej, red. A. Zeidler-Janiszewska, Instytut Kultury, Warszawa 1993, s. 9.

E. Wilk Od Redaktora, „Przegląd Kulturoznawczy” 2007 nr 2, s. 5.

Kontekst literacki snu pod kątem estetyki/filozofii miasta i jego architektury głównie na podstawie Pasaży (wyrywkowo z innych dzieł W. Benjamina) omawia J. Borowczyk w swojej pracy Poeta przebudzenia, w: Wokół „Pasaży" Waltera Benjamina, red. P. Śniedziewski, K. Trybuś, M. Wilczyński, Seria Filologia Polska Nr 115, Wydawnictwo Uniwersytetu Adama Mickiewicza w Poznaniu, Poznań 2009, s. 138-152.

7 W. Benjamin DerSurrealismus, w: tegoż Gesammelte Schriften, t. 2, Suhrkamp Verlag, Frankfurt am Main 1988, s. 308. Cyt. za: A. Lipszyc To nie moja historia „ "Dwutygodnik” 3/2010 nr 26, http:// www.dwutygodnik.com/artykul/951-to-nie-moja-historia.html (15.02.2016).

8 B. Lindner Benjamin Handbuch: Leben - Werk - Wirkung, J.B. Metzler, Stuttgart-Weimar 2011, s. 674 . 
dziele - w Pasażach, ale również np. w Ulicy jednokierunkowej. Początki tych zapisów w twórczości filozofa datuje się mniej więcej na połowę lat 20. ubiegłego stulecia. Zakłada się, że bodźcem dla nich były popularna wówczas teoria psychoanalizy oraz rodząca się kultura surrealistyczna. Bardziej jednak niż psychoanalizą i interpretacją snów (Traumdeutung) Benjamin interesował się samymi snami. Nazywał sen „świecką inspiracją/iluminacją"” (profane Erleuchtung) i łączył tę refleksję z krytyką surrealizmu oraz zdystansowaniem się do surrealistycznego pojmowania sztuki ${ }^{10}$. Często przywoływał anegdotę związaną z Manifestem surrealizmu André Bretona i francuskim poetą Paul-Pierre'em Roux, który przed pójściem spać umieszczał na swoich drzwiach tabliczkę "Le poète travaille” - czyli poeta pracuje ${ }^{11}$. Swoje obrazy senne Benjamin zwykł opowiadać przyjaciołom, czym wprawiał ich często w zdumienie, a nierzadko irytował. Około 1920 roku utrzymywał, że przyśniła mu się śmierć jego ciotki ${ }^{12}$. Z kolei w eseju Doświadczenie i ubóstwo ${ }^{13}$ znajduje się następująca uwaga dotycząca snu: „Sen jest konsekwencją zmęczenia i nierzadko rekompensuje smutek i zniechęcenie dnia codziennego, pokazując siłę prawdziwego bytu, któremu jej brak na jawie"14. Rozważania o śnie Waltera Benjamina cechują się indywidualnością stylu. To właśnie Benjamin wysunął tezę o historyczności snu, tj. udziale snu w procesie historycznym. Postrzegał sny jako obrazy mentalne i zagadki obrazkowe. Postrzeganie snu jako obrazu wskazuje więc, że sen ma strukturę językową, czego wymownym dowodem jest fragment Ulicy jednokierunkowej $j^{15}$ :

Mądrość ludowa przestrzega przed opowiadaniem snów rano na czczo. Taki przebudzony pozostaje w rzeczywistości jeszcze pod czarem snu. Mycie wydobywa na światło dzienne tylko powierzchnię ciała i jego widoczne funkcje motoryczne, gdy tymczasem w głębszych warstwach także podczas ablucji w świetle poranka trwa szara pomroka snu, a nawet

9 Tamże.

10 Tamże.

11 Tamże.

12 Tamże.

13 Tamże.

14 Tamże [tłumaczenie $z$ j. niem. - J.K.].

15 W. Benjamin Ulica jednokierunkowa, przeł. B. Baran, Aletheia, Warszawa 2010, s. 17-18. 
umacnia się w samotności pierwszej godziny po przebudzeniu. Kto się obawia spotkania z dniem - czy to z lęku przed ludźmi, czy ze względu na wewnętrzne skupienie - temu nie chce się jeść i rezygnuje ze śniadania. [...] Tylko bowiem z innego brzegu, od strony jasnego dnia, można podjacć sen z perspektywy poddanego namysłowi wspomnienia. [...] Następuje ono przez żołądek. Na czczo człowiek mówi o śnie, jakby mówił przez sen. ${ }^{16}$

Figura snu, jaką pisarz konstruuje w powyższym fragmencie zatytułowanym Bar śniadaniowy, to figura zawieszona między rytuałem ablucji a doświadczeniem flanera - miejskiego spacerowicza. To doświadczenie przenosi nas od razu w przestrzeń miejską. Snu nie wolno opowiadać na czczo - poranna toaleta odsłania w dalszym ciągu jedynie cielesność śpiącego (śniącego) człowieka. Treści, jakie wyłaniają się z tego fragmentu, to przede wszystkim uderzająca świadomość bytu we śnie i bytu śpiącego w ogóle, zawieszenie między światem nocnym a dziennym. Problem polega na ustaleniu, gdzie zaczyna się i czy w ogóle możliwy jest etap narracji o śnie ${ }^{17}$. Podążając za Benjaminem - jak można opowiedzieć sen, nie naruszając granic świata nocnego i dziennego? Pisarz przestrzega śniącego przed zwracaniem się ku dziennej rzeczywistości, a w słowach „przeciwległą stronę snu można osiągnąć tylko w oczyszczeniu, analogicznym do ablucji, lecz zupełnie od niej odmiennym"18 podkreśla wzajemne warunkowanie się dwóch centralnych kategorii - świadomości oraz istnienia śniącego bytu. Można spróbować wytłumaczyć to, odnosząc się do tantry jogi najwyższej, w świetle której sama wiedza o tym, że spaliśmy, jest dowodem na to, że istnieliśmy w tym czasie. Wiedza ta prowadzi więc do wniosku, że nasza egzystencja to nic innego jak właśnie sen ${ }^{19}$. Przemyślenia Benjamina na temat snu jako matrycy ludzkiej egzystencji można odnaleźć również w zapisach O haszyszuº:

16 Tamże.

17 Technice narracji, w której motyw snu został wykorzystany jako narzędzie interpretacji fabuły oraz jako sieć powiązań intertekstualnych, poświęciła swoją uwagę A. Buda w pracy Between Dream and Reality: Various Images of Dream in the Works by Antonia Susan Byatt, w: W. Owczarski, Z. Ziermann Dreams, Phantasms and Memories, Wydawnictwo UG, Gdańsk 2015, s. 301-312. W. Benjamin Ulica jednokierunkowa, s. 18. Maha Joga http://mahajoga.org/skrot.html (15.02.2016). W. Benjamin O haszyszu. Teksty literackie, zapiski, materiały, przeł. E. Drzazgowska, Aletheia, Warszawa 2010, s. 90. 
Palacz opium lub haszyszu doświadcza siły spojrzenia pozwalającej mu wyssać sto krain z jednego miejsca. Sen o poranku po paleniu. Jest tak powiedziałem - jak gdyby życie było niejako zamknięte w konserwie. Sen zaś jest jak gdyby płynem, w którym życie leżało i który teraz wypełniony wszystkimi jego zapachami zostaje odcedzony. ${ }^{21}$

Zatem bez względu na obszar i zakres refleksji związanej z doświadczeniem snu dwa elementy - świadomość oraz istnienie - są obligatoryjne, jeśli chcemy mówić np. o auratyczności snu, do czego odniosę się w odrębnej części szkicu.

Kwestię historyczności snu u Waltera Benjamina poruszył także w swojej pracy Ryszard Różanowski, dokonując przesunięcia Benjaminowskiego pojmowania snu w stronę snu jako kategorii szoku:

Emfaza, z jaką Benjamin przedstawia moment historyczny jako moment niebezpieczeństwa, wielokrotne powtarzanie słowa "nagle", nie dają się wyjaśnić tylko w oparciu o realną groźbę faszyzmu - mają one także podstawę estetyczną. Źródła jego koncepcji szoku tkwią niewątpliwie w poezji Baudelaire'a oraz w Wieśniaku paryskim Aragona. Cały szereg motywów pokrewnych koncepcji obrazu dialektycznego odnaleźć można w Nadji André Bretona: w negacji linearności, w odkryciu rewolucyjnych mocy, „w starociach”, w pierwszych konstrukcjach żelaznych, pierwszych zabudowaniach fabrycznych, najstarszych zdjęciach, przedmiotach na wymarciu, w salonowych fortepianach [...]. Również kompleks historycznego przebudzenia, nazwany przez Benjamina „wzorcowym przypadkiem myślenia dialektycznego" wywodzi się z surrealistycznej estetyki snu. ${ }^{22}$

Doświadczenie snu u Waltera Benjamina, jak wynika z przywołanego powyżej fragmentu, ,kołysze się" zatem między refleksją z pogranicza historii i autobiografii (ucieczka Benjamina przed nazistami zakończona śmiercią), komunikacji literackiej (Nadja A. Bretona - jeden z pierwszych literackich fototekstów) oraz nawiązaniem do estetycznego „przebudzenia” kultury architektonicznej (jako aluzja do XIX-wiecznego snu Paryża u progu

21 Tamże. 
nowoczesności $\left.{ }^{23}\right)$, a całość doświadczenia spowita jest dialektyką myślenia, tak charakterystyczną dla Benjamina - również dla jego pojęcia „Aury”, któremu poświęcę uwagę w kolejnej części szkicu.

\section{Pojęcie "dystansu" (oraz przybliżenia) a auratyczność snu - kilka słów O haszyszu Waltera Benjamina}

Dlaczego doświadczenie snu, a nie sen sam w sobie? Odpowiedź znajdziemy w eseju Benjamina pt. Doświadczenie i ubóstwo z 1933 roku²4. To w tym eseju pojawia się wyraźna zapowiedź końca umiejętności opowiadania o świecie. Rzeczywistość - przestrzeń komunikacyjna i kultura (treść komunikacji) zubożały. Jeśli z tej triady weźmiemy pod uwagę kulturę jako treść komunikacji, doprowadzi nas to do koncepcji auratyczności i samego pojęcia Aury, z której Walter Benjamin uczynił narzędzie badawcze służące do opisu przemian kultury, których on sam był świadkiem.

Skąd zaczerpnąłem pojęcie „dystansu”? Jest ono logiczną konsekwencją pojęcia aury, pojęcia z wielokrotnie przywoływanego we współczesnej refleksji humanistycznej eseju Dzieło sztuki w dobie jego reprodukcji technicznej (1936). W świetle Benjaminowskiej definicji aury oraz śladu - gdzie aura to "przejaw dali, bez względu na to, jak blisko dana rzecz może się znajdować"25, ślad z kolei „jest przejawem bliskości bez względu na to, jak daleko rzecz, która go pozostawiła, może być” ${ }^{26}$, pojęcie „dystansu", którego głównymi składnikami w estetyce myślenia Waltera Benjamina są właśnie perspektywy bliży i dali, rozpatruję jako możliwy element technicznego wymiaru analizowanego zjawiska snu. Aura jest specyficznym pojęciem u Waltera Benjamina, które łączy ściśle myśl techniczną z humanistyczną refleksją:

„Czymże właściwie jest aura?" - pyta wprost Benjamin. Osobliwa pajęczyna z przestrzeni i czasu: niepowtarzalne zjawisko pewnej dali, choćby była najbliżej. Aura, jak się wydaje, pozwala przybliżyć świat

23 L. Banowska Paryż "Pasaży”Waltera Benjamina-u progu nowoczesności, w: Wokół „Pasaży”Waltera Benjamina, s. 108.

24 K. Kopka Ciekawy przypadek Waltera Benjamina, 13.08.2014, http://teatralny.pl/felietony/ciekawy-przypadek-waltera-benjamina,642.html (15.02.2016).

B. Frydryczak Świat jako kolekcja. Próby analizy estetycznej natury nowoczesności, Wydawnictwo Fundacji Humaniora, Poznań 2002, s. 165. 
przedmiotów, uczynić go istniejącym dla nas jako ślad naszego poczucia urody i sensu istnienia. Jednak może pojawić się jako stylizacja, kostium powielający świadomościowe konwenanse... ${ }^{\mathbf{2 7}}$

„Aura” może być zatem również, oprócz implikacji w komunikacji literackiej ${ }^{\mathbf{2}}$, punktem odniesienia dla doświadczenia snu - „stylizacją” świadomości i „kostiumem”, jaki dla celów eksperymentu przywdziewamy, aby sprawdzić własne możliwości poznawcze. Jeśliby przyjąć, że obydwie nadrzędne kategorie - przyjemności (radości, zabawy) i bólu (cierpienia, zatracenia) - wpisują się we współczesną postmodernistyczną regułę tzw. podwójnego kodu²9 - czyli zasadę mówiącą o łączeniu sprzecznych konwencji - a także wpisują się w zasadę hybrydyzacji (krzyżowania nurtów i gatunków, np. w formie tekstowo-obrazowej) oraz w estetykę nadmiaru (niedookreśloności, fragmentaryczności zamiast regularnej kompozycji) ${ }^{30}$, to książka O haszyszu Benjamina i czas, w którym powstała, czynią tę pozycję dość innowacyjną we współczesnej kulturze. Z czego składa się ta książka? Mamy tutaj różne formy tekstów cechujących się mniejszym lub większym stopniem literackości: jeden esej, tekst teoretyczny i liczne protokoły z zapisów narkotycznych Benjamina i jego przyjaciół, notatki w formie pojedynczych, często sprawiających wrażenie (przynajmniej pod względem ich zawartości merytorycznej) niedokończonych zdań, a także aneks do protokołów w postaci obrazków - rysunków powstałych pod wpływem zażycia określonego środka odurzającego. Głównym punktem odniesienia dla książki są oczywiście odmienne stany świadomości spowodowane zażyciem określonego środka odurzającego ${ }^{31}$ - haszyszu, opium, meskaliny

27 A. Jamroziakowa Fotografia - simulacrum i inaczej nas nie ma, w: „Drobne rysy w ciągłej katastrofie...", s. 184.

J. Kowalski Jeszcze tradycyjna czy już „nowa” filologia? Wstronę rozważań Waltera Benjamina, „Radomskie Studia Filologiczne" 2015 nr 2/3, S. 119.

A. Kaliszewski Główne nurty w kulturze XX iXXI wieku, Poltext, Warszawa 2012, s. 199.

Tamże.

31 Warto przywołać tu pracę angielskiego literaturoznawcy Philipa Glennie, który w pierwszoosobowych relacjach opisujących odurzanie się narkotykami (na przykładzie Jeana Cocteau, Aldousa Huxleya i Waltera Benjamina) upatruje możliwości dostarczenia czytelnikowi wiedzy o strukturach jakościowych dotyczących przestrzeni, czasu, pożądania i wcieleń. Przedstawiają one subiektywne doświadczenia wymienionych autorów, którzy, odczuwając ból egzystencjalny, doznają ulgi przed śmiercią dzięki zażywaniu narkotyków. Analiza została przeprowadzona na podstawie teorii Jacques'a Lacana, Georges'a Bataille'a, Maurice'a Merleau-Ponty'ego 
oraz oksykodonu (także pod nazwą eukodal), których celem było zweryfikowanie możliwości poznawczo-intelektualnych, z dużym naciskiem na literacką moc twórczą. Wszystkie te środki wywołują efekty uboczne, spośród których jednym jest właśnie senność:

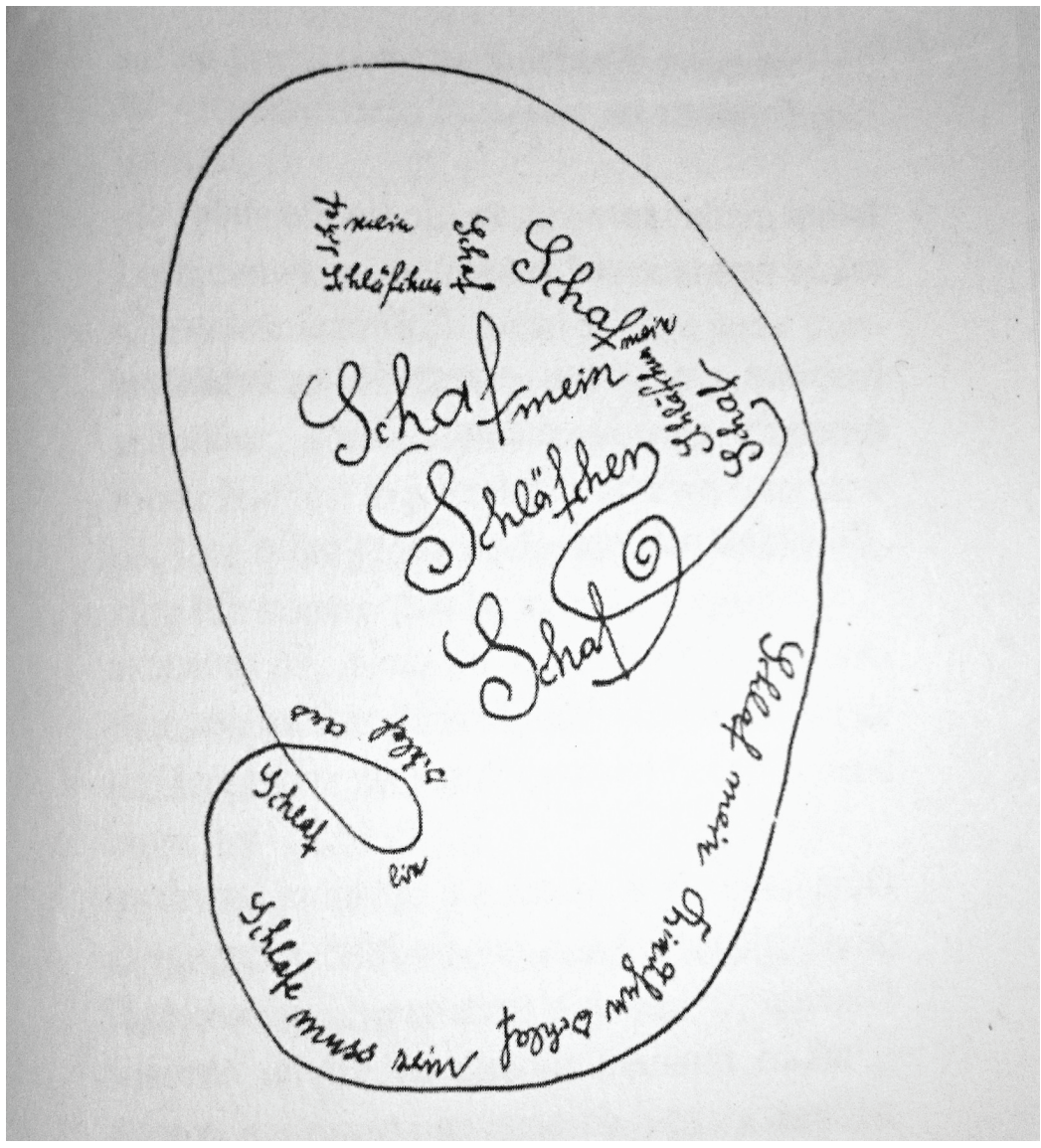

[W.Benjamin O haszyszu. Teksty literackie, zapiski, materiały, Ilustracja 1, s. 209.]

i Martina Heideggera. P. Glennie Feeling Better: The Therapeutic Drug in Modernism, http://ir.lib. uwo.ca/cgi/viewcontent.cgi?article=1374Econtext=etd (15.02.2016). 


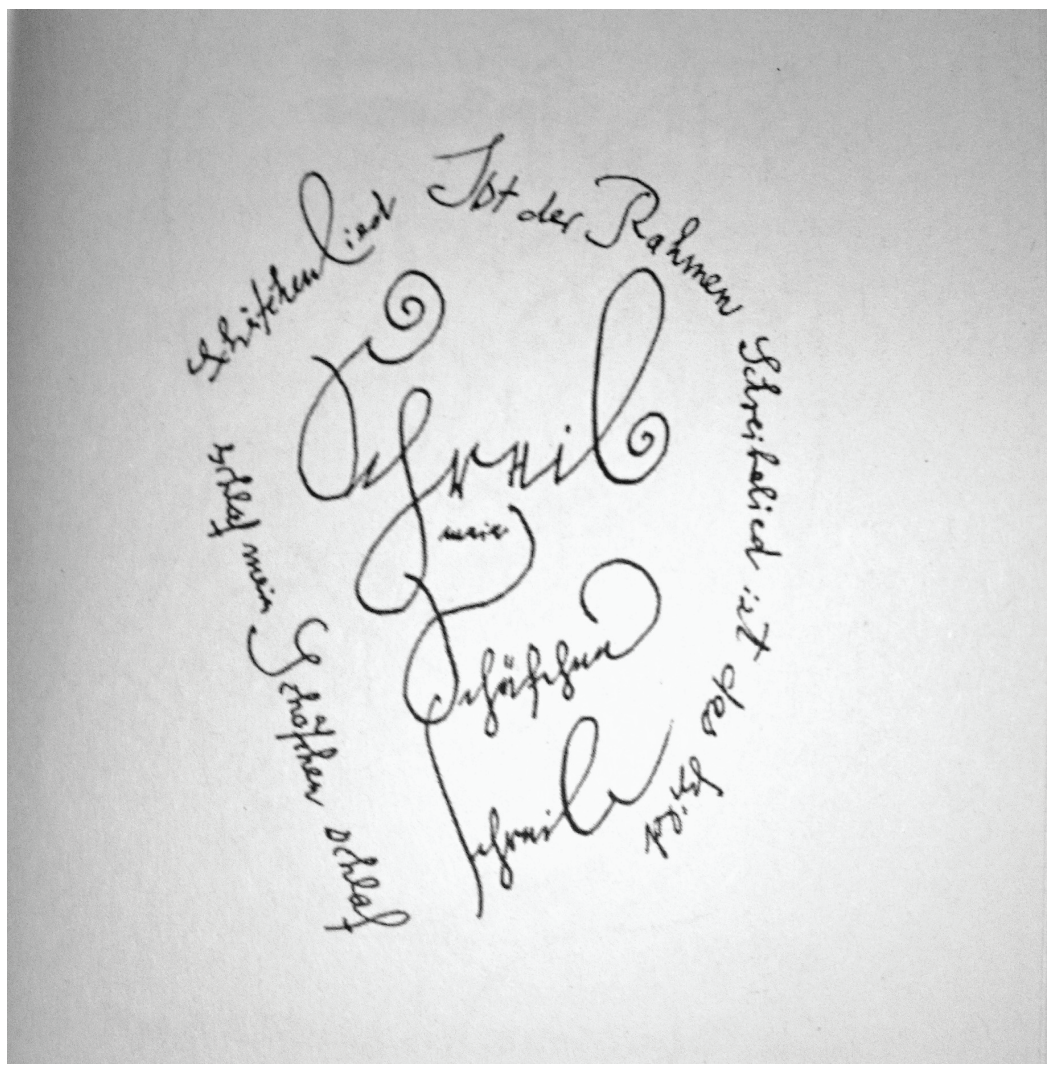

[W.Benjamin O haszyszu. Teksty literackie, zapiski, materiały, llustracja 1, s. 211.]

W zapiskach Waltera Benjamina związanych z eksperymentami narkotycznymi czytamy:

By zbliżyć się do zagadki szczęścia odurzenia, trzeba się zastanowić nad nicią Ariadny. Jakaż przyjemność w samym akcie rozwijania kłębka. Głęboko pokrewna przyjemności rauszu, ale także tworzenia. Posuwamy się naprzód; nie tylko odkrywamy jednak przy tym zakręty jaskini, do której ośmieliliśmy się wejść, lecz ponadto możemy się cieszyć tym szczęściem odkrywców jedynie z racji drugiej rytmicznej długości - rozwijania kłębka. Pewność, którą zawdzięczamy rozwijaniu kunsztownie zwiniętego kłębka - czyż nie jest szczęściem wszelkiej, przynajmniej prozatorskiej 
wytwórczości? A pod wpływem haszyszu jesteśmy czerpiącymi przyjemność istotami prozatorskimi najwyższej potencji. ${ }^{32}$

Imaginacja senna - będąca efektem zażycia środka odurzającego bądź konkretnego rodzaju narkotyku - jest formą ekstensji świadomości ludzkiej, a więc ma zweryfikować możliwości poznawcze człowieka, który zostaje uwikłany w grę między przyjemnością a cierpieniem, miłością a śmiercią, krótkotrwałą radością ${ }^{33}$ a wyciszeniem bolesnej egzystencji. Rausz służy osiąganiu przyjemności i ucieczce od świata realnego - „bliskości Erosa” $i$ „oddalenia Tanatosa”, choć ten drugi jest ciągle w pobliżu: „Bliskość śmierci sformułowała mi się wczoraj w zdaniu: śmierć znajduje się między mną a moim rauszem" ${ }^{34}$. Cały czas zatem obserwujemy operowanie pojęciami bliży i dali, czyli głównymi składnikami pojęcia „Aury”. Sen, jako skutek uboczny, jest w sposób jednoznaczny związany z doświadczeniem (odczuwaniem) przyjemności lub jej brakiem. Tak samo jak narkotycznemu rauszowi, również doświadczeniu snu Benjamin przypisuje właściwości związane z interpretowaniem, odkrywaniem rzeczywistości. Nie bez znaczenia pozostaje to, że koncepcja „Aury” znana z eseju Dzieło sztuki w dobie jego reprodukcji technicznej ma swoje źródło właśnie w prowadzonych eksperymentach z haszyszem ${ }^{35}$. Jeden z kuzynów Waltera Benjamina, lekarz z wykształcenia i jeden z uczestników eksperymentów haszyszowych, sporządził na początku marca 1930 roku taki oto zapis:

Niektóre późniejsze wypowiedzi G. świadczą o tym, że odurzenie mimo wszystko było tak głębokie, iż umknęły mi słowa i obrazy z pewnych stadiów. Ponieważ zaś kontakt z innymi jest konieczny, by odurzony mógł językowo i myślowo wyrazić swe doznania, to już z powyższego można wywnioskować, że wynik intelektualny miał się tym razem nijak do głębokości rauszu i, jeśli kto chce, do przyjemności. Tym więcej powodów, by wydobyć to, co zarówno wedle relacji G., jak i moich

W. Benjamin O haszyszu, s. 74.

Powtórzenia w zapisie prowadzonych eksperymentów Waltera Benjamina mogą być odczytane jako dowód na mechaniczne - a więc odtwarzalne, powtarzalne osiąganie stanu przyjemności - nie tylko ze względu na to, że dotyczą samego Benjamina, ale i innych osób, które brały udział w eksperymentach.

W. Benjamin O haszyszu, s. 107.

B. Lindner Benjamin Handbuch, s. 677. 
wspomnień jawi się jako sedno tego eksperymentu. Chodzi o moje wypowiedzi na temat istoty aury [wyróż. - J.K.]. Wszystko wówczas, co mówiłem, miało polemiczne ostrze wymierzone w teozofów, których brak doświadczenia oraz ignorancja wysoce mnie gorszyły. Pod trzema względami przeciwstawiłem - bynajmniej nie schematycznie - prawdziwą aurę konwencjonalnym, banalnym wyobrażeniom teozofów. Po pierwsze, prawdziwa aura towarzyszy wszystkim rzeczom. Nie tylko niektórym, jak ludzie mniemają. Po drugie, zmienia się zupełnie, w sposób zasadniczy z każdym ruchem, jaki wykonuje przynależna jej rzecz. Po trzecie, prawdziwej aury nie można przedstawiać sobie jako nieskazitelnych, spirytualistycznych, magicznych promieni, tak jak się to robi w prymitywnych książkach mistycznych. Wyróżnikiem prawdziwej aury jest raczej ornament, obrzeże ornamentowe, w którym rzecz lub istota tkwi niczym w futerale. ${ }^{36}$

Zbliżony charakter uwagi dotyczący pojęcia "Aury” odnajdziemy w pracy innej, równie wpływowej myślicielki XX wieku - Hannah Arendt, która podkreśla, że:

owa aura, przyrodzona lub sztuczna, skrywająca nieosiągalne, a jednocześnie nieodparcie sugestywne „tu i teraz”, stanowi o autentyczności tak ludzi, jak i przedmiotów [wyróż. - J.K.] i jako taka podlega historycznemu przekazowi. To zatem, co Benjamin odnajdywał w kolekcjonowanych przez siebie rzeczach, to ich aura, tyleż odsłaniająca, co skrywająca „zawartość prawdy". [...] Tym samym wraz z utratą aury przedmioty tracą znamię naturalności, ów niezniszczalny aspekt wiecznego „tu i teraz", który podlegał międzypokoleniowemu przekazowi. ${ }^{37}$

Aura jest zatem centralnym punktem odniesienia w twórczości Waltera Benjamina związanym z szeroko pojętą ludzką komunikacją kulturową, a nie tylko samym dziełem sztuki, ponieważ dzieła te nie stworzyły się same, tylko zyskały swój „przekaz”, tę auratyczną treść, za pomocą rąk ludzkich. Dlatego też eksperymenty związane ze środkami odurzającymi oraz wynikające z nich skutki uboczne (jak np. wspomniana senność) oraz dość obszerna

\footnotetext{
36 W. Benjamin O haszyszu, s. 161.

37 H. Arendt Walter Benjamin 1892-1940, przeł. A. Kopacki, słowo/obraz terytoria, Gdańsk 2007, s. 122.
} 
płaszczyzna wysiłków intelektualnych podejmowanych po zażyciu takich środków, głód doświadczenia poznawczego, stanowią kolejny ważny element w rozważaniach Waltera Benjamina nad komunikacją kulturową. W zapisach z eksperymentów haszyszowych można odnaleźć co najmniej kilka fragmentów poświęconych auratycznej naturze rzeczywistości. Naturalnie trzeba odróżnić rzeczywistość percypowaną na trzeźwo i rzeczywistość po zażyciu środka odurzającego. Gdzieś między tymi płaszczyznami sytuuje się doświadczenie snu - względnie fizycznego sennego odurzenia - i spowodowane tym określone postrzeganie rzeczywistości.

Na tym tle ciekawie wypada protokół z 18 kwietnia 1931 roku: po zażyciu 1 grama haszyszu p.e., czyli podmiot eksperymentu, doznaje szeregu efektów językowo-twórczych (związanych zarówno z postrzeganiem, jak i tego opisywaniem): od skłonności do zdrobnień, delikatności w języku aż po bodźce zmysłowe związane $\mathrm{z}$ widzeniem obrazów i towarzyszących im kolorów. Podmiot eksperymentu wyraźnie podkreśla, że chciałby „zobaczyć coś pięknego"38.

Senność wywołana odurzeniem powoduje widzenie krajobrazowe - myśl, którą można bardzo łatwo połączyć z dalszą problematyką pojęcia "Aury" u Benjamina: „Odpoczywając w letnie popołudnie, wodzimy oczami po górach na horyzoncie lub po gałęzi, która rzuca swój cień na nas - oddychamy aurą tych gór czy tej gałęzi" ${ }^{39}$. Czego natomiast doświadcza podmiot eksperymentu w stanie sennego odurzenia? Tak oto zintensyfikowane efekty po zażyciu środka odurzającego kumulują się w jego słowach: „Wszystkie odgłosy same z siebie nabrzmiewają razem w krajobrazy [...]. Westchnienie podobne widokowi [...] ([dal - dopisek - J.K.] rozpościerała się mu przed oczyma przywiana wiatrem. Dal [zbliża - dopisek - J.K.] się do oddechu w tej mierze, w jakiej oddala się od wzroku)"40. Podmiot eksperymentu w sennym odurzeniu operuje perspektywą bliskości i oddalenia - składowymi pojęciami „Aury”, ponieważ postrzega rzeczywistość w schematach krajobrazowych i doświadcza wręcz astrologicznych wizji. Po dwóch godzinach eksperymentu zapada w całkowity sen.

38 W. Benjamin O haszyszu, s. 186.

39 „An einem Sommernachmittag ruhend einem Gebirgszug am Horizont oder einem Zweig folgen, der seinen Schatten auf den Ruhenden wirft - das heißt die Aura dieser Berge, dieses Zweiges atmen", tegoż, Das Kunstwerk im Zeitalter seiner Reproduzierbarkeit, Reclam, Stuttgart 2011, s. 17. 


\section{Współczesne praktyki senne - kilka słów o twórczej działalności Joanny Rajkowskiej}

Czym jest w kontekście niniejszych Benjaminowskich rozważań współczesne doświadczenie snu? Doświadczeniem jednostki ludzkiej uciekającej przed bolesną wizją rzeczywistości i szukającej ukojenia, nieopisanej przyjemności w wytworach wyobraźni własnego umysłu? Kolejnym dowodem współistnienia Erosa i Tanatosa? Przykład zdaje się trywialny, jednak znaczący: "galeria XXI wieku" jako wyobrażenie miejsca (budynku) i ogniska interakcji międzyludzkiej (handlowej, form spędzania wolnego czasu) stało się przestrzenią konsumpcjonizmu, a utraciło charakter przestrzeni, w której można obcować ze sztuką. Eksperyment polegający na umieszczeniu w takiej "galerii” śpiących ludzi może być rozumiany jako ukazanie życia jako snu o utraconym doświadczeniu piękna, czyli praktycznym wymiarze auratycznym snu. Sen staje się zatem futerałem doświadczenia auratycznego w rozumieniu Waltera Benjamina - jest właśnie formą doświadczenia, a nie snem samym w sobie. Jak stwierdza sam autor: „I nie ma wątpliwości, że prawdziwe piękno, iluminacja pozostają uśpione" ${ }^{\text {"41 }}$. Tak bliskie, bo niemal rzeczywiste - i tak dalekie, bo uśpione. Do tego, by doświadczyć utraconego piękna, potrzebny jest środek wspomagający - nie musi to, naturalnie, być środek silnie odurzający, jak w przypadku eksperymentów Waltera Benjamina i osób z jego otoczenia, ale coś, co wzbudza w człowieku przygotowującym się do snu poczucie wewnętrznej estetyki, obrazu będącego określonym odzwierciedleniem pozytywnego stanu umysłu, a więc elementarnego sensu związanego z ludzką świadomością - bliskością jako aktem poznawczym.

Przykłady współczesnych praktyk związanych z estetyką snu, które pokazują doświadczenie Benjaminowskiej auratyczności, odnajdziemy w działalności twórczej Joanny Rajkowskiej (ur. 1968), artystki i performerki tworzącej instalacje w przestrzeni publicznej. Jednym z jej eksperymentów był projekt publiczny pt. Dziennik snów - Galeria XX1 z 2001 roku. Poniżej szczegółowy opis projektu:

Między 3 a 8 września 2001 galeria XX1 stała się miejscem snu. Spotkało się tam około 250 osób chętnych zasnąć za dnia na parę godzin w miejscu publicznym. Zostały dla nich przygotowane dwa materace wielkości $7 \mathrm{x}$ $4 \mathrm{~m}$ przykryte płótnem, lekkie kołdry i poduszki. Materace zostały rozmieszczone symetrycznie po obu stronach drzwi prowadzących z ulicy

Tamże, s. 74 . 
do galerii. Spało na nich przeciętnie 25 osób dziennie od 11-tej do 16tej. O 16-tej budziła ich muzyka napisana na prośbę artystki. Potem była jeszcze godzina na wybudzenie i zapisanie snu, o ile coś się przyśniło. Do ich zapisania posłużyły rozdane zeszyty. W ten sposób powstał (nigdy nie opublikowany) katalog Dziennika snów. Ludzie idący aleją Jana Pawła II mogli przez dwa duże okna galerii zobaczyć innych, którzy spali. Nie mogli jednak do galerii wejść. Akcent położony był na wyhamowanie wrażeń, śpiący ludzie i ich spokój byli ważniejsi niż transmisja ich snu. Dziennik snów był próbą zbudowania bliskości między ludźmi, którzy się nie znają. Ta intymność ma powstać poprzez zwykłe leżenie koło siebie, spanie. Była to również odpowiedź na sytuację, w której monopol na intymność ma rodzina - monopol prowadzący do wyizolowania ludzi poza rodzinami, do braku komunikacji. Dzielenie ludzi na swoich (związki krwi albo partner seksualny) i obcych sprawia, że zapominamy, że w pierwszym rzędzie jesteśmy tylko osobnym ciałem, które dopomina się bliskości z innym ciałem. Odpowiedź na list jednego z uczestników Dziennika snów: „Bycie ludzi ze sobą nie polega na posiadaniu wspólnego celu. Nawet, jeśli to się zdarza, to kuleje lub ulega skostnieniu - przekształca się w instytucję, we władzę, w suchą formułę; zobacz jak wyglądają wspólnoty ludzi: partia polityczna, kościół, związek zawodowy... Nie wierzę we wspólną walkę o cokolwiek a we wspólnotę polityczną wierzę najmniej. Być może tego typu działanie buduje tzw. wspólny cel definiowany negatywnie na zasadzie wspólnego wroga. Ja nie chcę wymyślać celów, pod jakimi ludzie będą się jednoczyć. Nie wierzę nawet w to, że nasze bycie ma jakikolwiek cel. Cóż dopiero mówić o celu mającym jednoczyć ludzi... Można budować jakiś sens, ale cel...? Przecież my jedynie spędzamy nasz czas tutaj. Moje bycie tak jak i twoje bycie jest przede wszystkim niewytłumaczalnym faktem biologicznym a potem wszystkim innym..."42

Wyraźnym punktem odniesienia widocznym w opisie projektu sennego jest perspektywa snu jako konkretnego działania dla wyrażenia bliskości (czystego aktu komunikacji między przypadkowymi ludźmi). Ludzie ci - w myśl kategorii performatywnej - także eksperymentowali na własnym ciele, ponieważ zgodzili się „przywdziać” kostium pewnego stanu świadomości i wypełnili konwencjonalne założenia projektu (praktyki) snu. Spali niczym

42 J. Rajkowska Dziennik snów. Projekt publiczny, http://www.rajkowska.com/pl/projektyp/7 (15.02.2016). Zachowano pisownię oryginalną. 
zaprogramowani, a budziła ich muzyka Joanny Rajkowskiej - a zatem dość pobudzający środek estetyczny. Sen nie może stanowić wspólnego celu dla określonej grupy przypadkowych ludzi, ponieważ wspólny cel sam w sobie prowadzi do wykluczenia („skostnienia”) komunikacji grupowej i jej poszczególnych form (instytucji, partii, kościoła, związków zawodowych). To samotność jest największym narkotykiem współczesności, dlatego każda z biorących w projekcie sennym osób opisała swoje własne „doświadczenie” snu. Sen musi mieć swój punkt odniesienia. Co pomagało w zasypianiu? Na swojej stronie internetowej Rajkowska umieściła obrazki z opakowań herbaty różnego rodzaju. Obrazki miały sugerować, jakie czynniki, wedle producentów herbaty, mają kojarzyć się ze snem i wyciszeniem. Musiały zatem oddziaływać na wyobraźnię śpiących ludzi, dawać do myślenia, być tym bodźcem snu jako doświadczenia. U podstaw takiego eksperymentu sennego leży zatem określona wizja doświadczenia estetycznego - doświadczenia piękna, którego nie dałoby się lepiej zrealizować niż za pomocą praktyki sennej, dla której określony obraz oraz muzyka są twórczymi podstawami działania. Sen to ciało i obraz. W niedatowanych zapiskach z książki $O$ haszyszu Benjamin pisał, że „każdy obraz jest snem dla siebie”43, a „działanie jest sposobem by śnić" Tak jak w przywołanym eksperymencie Rajkowskiej - sen stał się jednym z współczesnych przykładów performansu, doświadczeniem stanowiącym rodzaj lekarstwa na dzisiejsze symptomy pęknięcia ponowoczesności (świata auratycznego, tj. świata „odczarowanego" 45 zgodnie z myślą Benjaminowską), w którym kopia kopii nie ma nic wspólnego z niepowtarzalnym oryginałem, a ludzie, odurzeni codziennością, zamiast z galerią sztuki, obcują z galerią XXI wieku - futerałem rzeczywistości piękna, w którym nawet sen stał się już tylko doświadczeniem.

44 Tamże, s. 215.

N. Michna Waltera Benjamina koncepcja sztuki odczarowanej, http://www.academia. edu/10022332/Waltera_Benjamina_koncepcja_sztuki_odczarowanej_Walter_Benjamin_s_ concept_of_disenchanted_art_(15.02.2016). 


\section{Abstract}

\section{Jacek Kowalski}

KAZIMIERZ PUŁASKI UNIVERSITY OF TECHNOLOGY AND HUMANITIES IN RADOM

Cultural Performance - Walter Benjamin's Experience of Dreaming

This paper consists of four parts. The first analyses the phenomenon of the dream as auratic experience; the second synthesises Benjamin's experience of the dream with reference to recent research; the third explores Benjamin's experience of the dream across his output; the fourth attempts to understand contemporary dream activities (on the basis of the works by a performer - Joanna Rajkowska) through Benjamin's experience of dream.

\section{Keywords}

dream, performance, auratic experience, Walter Benjamin, contemporary culture 